\title{
HUBUNGAN PENDAMPINGAN ANGGOTA KELUARGA DENGAN PERILAKU PENCARIAN PENGOBATAN PADA ORANG DENGAN HIV/AIDS
}

\author{
Gina Fitri Diati Ninda \\ Program Studi Kesehatan Masyarakat, Stikes Bhakti Husada Mulia Madiun \\ ginaninda28@gmail.com
}

\begin{abstract}
HIV / AIDS is a disease that has yet to be resolved. Based on statistical data of HIV / AIDS sufferers in the world, more than 35 million people are infected with HIV / AIDS. The inappropriate treatmentseeking behavior by odha is related to the lack of assistance from family members to support the treatment process that ODHA must live a lifetime. This study aims to determine the relationship between family members' income and treatment-seeking behavior in people with HIV / AIDS in Madiun Regency. This type of research is a quantitative study with a cross-sectional research design. The study population was 534 ODHA with a total sample size of 39 respondents. Analysis of the relationship in this study using the Chi-Square test. The results of the research from the Chi-Square test showed that Asymp. Sig results were $0.000 \leq 0.05$ with a prevalence ratio value of 0.105 . The test criterion is that $H O$ is rejected if Asymp.Sig $\leq 0.05$. So the results show that HO is rejected and there is a relationship between mentoring family members and treatment-seeking behavior in people with HIV I AIDS in the Madiun Regency area. This study concludes that the assistance provided by members will support the appropriate treatment-seeking behavior in people with HIV / AIDS. HIV/AID Prevention Comission of Madiun Regency have to try to do teamwork approach between family and ODHA to support the treatment process of ODHA.
\end{abstract}

Keywords: Mentoring, ODHA, Treatment-Seeking Behavior

\begin{abstract}
ABSTRAK
HIV/AIDS adalah penyakit yang hingga saat ini belum dapat terselesaikan. Berdasarkan data statistik penderita HIV/AIDS di dunia, lebih dari 35 juta orang terjangkit HIV/AIDS.Perilaku pencarian pengobatan yang kurang tepat dilakukan oleh ODHA dihubungani oleh kurangnya pendampingan dari anggota keluarga untuk mendukung proses pengobatan yang harus dijalani seumur hidup oleh ODHA. Penelitian ini bertujuan untuk mengetahui hubungan pendapingan anggota keluarga dengan perilaku pencarian pengobatan pada orang dengan HIV/AIDS di wilayah Kabupaten Madiun. Jenis penelitian ini merupakan penelitian kuantitatif dengan desain penelitian cross sectional. Populasi penelitian sebanyak 534 ODHA dengan jumlah sampel sebanyak 39 responden. Analisis hubungan dalam penelitian ini menggunakan uji Chi Square. Hasil Penelitian dari Uji Chi Square didapatkan hasil Asymp.Sig 0,000 $\leq 0,05$ dengan nilai ratio prevalens sebesar 0,105. Adapun kriteria pengujian adalah H0 ditolak jika Asymp.Sig $\leq 0,05$. Maka hasil menunjukan H0 ditolak dan terdapat hubungan antara pendampingan anggota keluarga dengan perilaku pencarian pengobatan pada orang dengan HIV/AIDS di wilayah Kabupaten Madiun. Kesimpulan dari penelitian ini adalah pendampingan yang diberikan oleh anggota akan mendukung perilaku pencarian pengobatan yang tepat yang pada orang dengan HIV/AIDS. Bagi KPAD Kabupaten Madiun diharapkan dapat melakukan pendekatan bersama kembali untuk memberikan konseling, informasi, dan edukasi atau KIE khususnya pada anggota keluarga yang masih belum mau memberikan pendampingan dan bahkan memberikan stigma pada orang dengan HIV AIDS
\end{abstract}

Kata Kunci : ODHA, Pendampingan, Perilaku Pencarian Pengobatan. 


\section{PENDAHULUAN}

HIV/AIDS salah satu penyakit yang hingga saat ini masih belum dapat terselesaikan. Hal ini dikarenakan penyakit HIV/AIDS belum ditemukan obat yang dapat menyembuhkan secara total dan jumlah penderitanya terus mengalami peningkatan setiap tahunnya. Tidak hanya masalah bagi kesehatan, HIV/AIDS juga telah menjadi permasalahan bagi pembangunan dan sosial. HIV (Human Immunodeficiency Virus) adalah sejenis virus yang menyerang sistem kekebalan dan dapat melemahkan kemampuan seseorang untuk melawan penyakit lain dengan memusnahkan sel-sel penting yang berfungsi mengendalikan dan mendukung sistem kekebalan tubuh manusia. Kumpulan gejala penyakit yang timbul akibat menurunnya kekebalan tubuh tersebut disebut dengan AIDS (Acquired Immunodeficiency Syndrome).

Berdasarkan data statistik penderita HIV/AIDS di dunia, lebih dari 35 juta orang sekarang hidup dengan HIV/AIDS (UNAIDS, 2018). Tahun 2017, berdasarkan data dari UNAIDS terdapat 36,9 juta masyarakat berbagai negara terinfeksi HIV dan AIDS. Total penderita yang ada, 1,8 juta di antaranya adalah anak-anak dan remaja berusia di bawah 15 tahun. Sebagian lain adalah orang dewasa, sejumlah 35,1 juta penderita. Berdasarkan data tersebut penderita HIV/AIDS wanita lebih banyak terinfeksi HIV/AIDS, yakni sebanyak 18,2 juta penderita. Sementara prevalensi HIV/AIDS pada laki-laki sebanyak 16,9 juta penderita.

Indonesia termasuk negara yang mengalami peningkatan kasus HIV/AIDS setiap tahunnya. Selain itu, Indonesia termasuk negara yang penduduknya paling berisiko terjangkit HIV/AIDS (Anggarini and Ary, 2014).AIDS di Indonesia selalu mengalami peningkatan sejak dilaporkan pertama kali tahun 1987 (Luthfiana, 2012).

Berdasarkan profil kesehatan Republik Indonesia, prevalensi HIV di
Indonesia yang dilaporkan secara resmi oleh Ditjen P2P, Kementrian Kesehatan RI pada tahun 2016 sebanyak 41.250 kasus dan pada tahun 201748.300 kasus. Sedangkan prevalensi kasus AIDS di Indonesia pada tahun 2016 (Kementerian Kesehatan Republik Indonesia, 2016) sebanyak 7.491 kasus dan pada tahun 2017 sebanyak 9.280 kasus (Departemen Kesehatan RI, 2018). Untuk tahun 2018 sampai dengan bulan Juni 2018 telah ditemukan penderita HIV/AIDS sebanyak 301.959 kasus (Departemen Kesehatan RI, 2018) .

Profil Kesehatan Provinsi Jawa Timur menunjukan bahwa jumlah kasus HIV/AIDS di Provinsi Jawa Timur jumlah kasus AIDS yang dilaporkan sampai Desember 2016 adalah 17.394 orang (Departemen Kesehatan Jawa Timur, 2017), dan 36.881 kasus HIV dari jumlah tersebut 3.679 diantaranya meninggal. (Profil kesehatan Jawa Timur, 2016). Pada tahun 2017 sebanyak 43.658 kasus HIV/AIDS dilaporkan oleh pihak Komisi Penanggulangan AIDS Jawa Timur. Pada tahun 2018 sampai dengan bulan Juni 2018 dilaporkan sebanyak 43.399 kasus telah ditemukan di Jawa Timur (Komisi Penanggulangan AIDS Jawa Timur, 2019)

Berdasarkan data dari KPAD Kabupaten Madiun temuan kasus HIV/AIDS di Kabupaten Madiun ditemukan pertama kali pada tahun 2002 sampai tahun 2019 (per bulan Juli) terjadi peningkatan setiap tahunnya. Dari data KPAD Kabupaten Madiun jumlah penderita HIV sejak tahun 2000 sampai dengan bulan Juli tahun 2019 mencapai 475 orang, sedangkan jumlah penderita AIDS sejak tahun 2002 sampai dengan Juli 2019 mencapai 282 orang. Baerdasarkan data tersebut terdapat ODHA komulatif atau yang masih hidup mencapai 534 orang, untuk ODHA yang meninggal sejak tahun 2002 sampai dengan Juli 2019 mencapai 223 orang (Komisi Penanggulangan AIDS Daerah Kabupaten Madiun, 2019). 
Berdasarkan faktor risiko di Kabupaten Madiun tahun 2002-2019 (per Juli) terbesar melalui perilaku heteroseksual sebanyak 304 kasus, selanjutnya pelanggan wanita pekerja seks (WPS) sebanyak 123 kasus, faktor lainnya sebanyak 108 kasus, IRT/Pasangan sebanyak 91 kasus, wanita pekerja seks langsung (WPSL) sebanyak 65 kasus, perinatal sebanyak 20 kasus, IDU/narkoba suntik sebanyak 13 kasus, waria sebanyak 12 kasus, gay sebanyak 15 kasus, dan dari ibu sebanyak 6 kasus (KPAD Kab Madiun, 2019).

Salah satu upaya yang dilakukan untuk pengendalian dan pencegahan penularan penyakit HIV/AIDS adalah dengan melakukan program pendampingan pada ODHA (Orang Dengan HIV/AIDS) maupun kelompok yang beresiko tinggi tertular HIV/AIDS. Pendampingan tidak hanya dilakukan oleh pihak KPAD secara langsung tetapi pendampingan juga dilakukan melalui pihak keluarga ODHA dengan arahan dan pemantauan dari KPAD Kabupaten Madiun. Pendampingan oleh pihak keluarga ODHA diharapkan dapat memotivasi ODHA agar dapat melakukan pengobatan secara teratur dan sesuai, selain itu pihak keluarga juga dapat membantu mengingatkan dan memberi arahan kepada ODHA untuk dapat mempertahankan kondisi kesehatannya sehingga tidak mengalami drop. Pendampingan oleh pihak keluarga kemungkinan sangat berperan pada keputusan ODHA dalam menentukan tindakan pengobatan atau perilaku pencarian pengobatan (Health seeking behavior).

Perilaku pencarian pengobatan (Health seeking behavior) adalah suatu usaha atau tindakan seseorang ketika mengalami sakit. Tindakan yang dimaksud antara lain dapat berupa tidak melakukan apa-apa atau tidak melakukan tindakan pengobatan (no action), tindakan melakukan pengobatan sendiri (self treatment), melakukan pengobatan ke fasilitas pengobatan tradisional (traditional remedy), dan melakukan upaya pengobatan ke fasilitas pengobatan modern yang disediakan oleh pemerintah atau lembaga kesehatan swasta dan dokter praktik.

Hingga saat ini masih terdapat ODHA yang belum mendapatkan pendampingan dari pihak keluarganya dan cenderung masih menutupi statusnya sebagai ODHA dikarenakan khawatir akan adanya stigma dan pelakuan yang tidak diharapkan dari pihak keluarganya Berdasarkan latar belakang dan penelitian sebelumnya menunjukkan bahwa penelitian ini berbeda dari segi variabel dengan penelitian yang telah dilakukan.

Maka dalam penelitian ini peneliti ingin mengatahui hubungan pendampingan anggota keluarga dengan perilaku pencarian pengobatan pada orang dengan HIV AIDS atau ODHA di Kabupaten Madiun. Berdasarkan latar belakang di atas, maka peneliti dapat merumuskan masalah sebagai berikut: Apakah ada hubungan pendampingan anggota keluarga dengan perilaku pencarian pengobatan pada orang dengan HIV AIDS di Kabupaten Madiun. Adapun tujuan dari penelitian ini adalah mengetahui hubungan pendampingan anggota keluarga dengan perilaku pencarian pengobatan pada orang dengan HIV AIDS di Kabupaten Madiun.

\section{METODE}

Metode yang digunakan dalam penelitian ini adalah penelitian kuantitatif dengan desain penelitian cross sectional untuk mempelajari dinamika korelasi antara faktor penyebab dengan efek atau hubungan yang ditimbulkan dengan cara pendekatan observasi atau pengumpulan data sekaligus pada satu waktu (point time approach). Penelitian ini dilakukan dengan tujuan menganalisis hubungan pemberian pendampingan anggota keluarga dengan perilaku pencarian pengobatan pada orang dengan HIV 
AIDS (ODHA) di Kabupaten Madiun (Sugiyono, 2007).

Populasi dalam penelitian ini adalah seluruh orang dengan HIV AIDS (ODHA) yang ada di Kabupaten Madiun dengan jumlah 534 orang. Sampel merupakan bagian dari populasi dan memiliki karakteristik yang memenuhi kriteria dan yang menjadi sampel penelitian adalah orang dengan HIV AIDS Kabupaten Madiun. Berdasarkan hasil penghitungan jumlah sampel ditemukan dari keseluruhan populasi orang dengan HIV/AIDS (ODHA) dengan jumlah 534 orang menggunakan rumus Lemeshow (Snedecor GW \& Cochran WG, 1967) (Lemeshow et al, 1997) ditemukan jumlah sampel yang dibutuhkan dalam penelitian ini sebanyak 39 responden.

\section{HASIL}

\section{Analisis Univariat}

Pada data demografi ini terdiri dari data usia, jenis kelamin, dan pendidikan dari 39 responden penelitian, yang dapat dilihat dalam tabel berikut:

\section{Usia}

Tabel 1. Frekuensi Data Usia Responden

\begin{tabular}{llllll}
\hline Variabel & Mean & Min & Max & Jumlah & $\begin{array}{c}\text { Persentase } \\
(\%)\end{array}$ \\
\hline Usia & 34,4 & 7 & 45 & 39 & 100
\end{tabular}

Sumber: Data Primer 2020

Berdasarkan tabel 5.1 diatas diketahui bahwa rentan usia 39 responden adalah 7 sampai 45 tahun dengan rata-rata usia 34,4 tahun.
Jenis Kelamin dan Pendidikan

Tabel 2. Frekuensi Data Jenis Kelamin dan Pendidikan Responden

\begin{tabular}{llrr}
\hline Variabel & Kriteria & Jumlah & \multicolumn{2}{c}{$\begin{array}{l}\text { Persentase } \\
(\boldsymbol{\%})\end{array}$} \\
\hline Jenis & Laki-laki & 18 & 46,2 \\
Kelamin & Perempuan & 21 & 53,8 \\
& & 4 & 10,3 \\
\hline Pendidika & SD & 1 & 2,6 \\
n & SMP & 34 & 87,2 \\
& SMA & &
\end{tabular}

Sumber: Data Primer 2020

Berdasarkan tabel diatas diketahui bahwa 94,9 \% responden berumur lebih dari sama dengan 30 tahun, responden perempuan lebih banyak dari responden laik laki dengan jumlah 21 orang atau $53 \%$ dari jumlah keseluruhan responden, sedangkan tingkat pendidikan responden sebagian besar yaitu $87,2 \%$ berpendidikan SMA.

\section{Variabel Pendampingan Keluarga}

Berikut adalah hasil analisis data dari variabel independen yaitu pendampingan oleh anggota keluarga dan variabel dependen yaitu perilaku pencarian pengobatan (Health Seeking Behavior) pada orang dengan HIV AIDS di wilayah Kabupaten Madiun yang telah didapat :

Tabel 3. Frekuensi Variabel Pendampingan keluarga

\begin{tabular}{lrr}
\hline $\begin{array}{c}\text { Variabel } \\
\text { Pendampingan } \\
\text { Keluarga }\end{array}$ & Frekuensi & $\begin{array}{c}\text { Persentase } \\
(\boldsymbol{\%})\end{array}$ \\
\hline Ya & 19 & 48,7 \\
Tidak & 20 & 51,3 \\
\hline Total & 39 & 100,0 \\
\hline Sumber: Data Primer 2020 & &
\end{tabular}

Berdasarkan tabel 5.2 diatas diketahui bahwa dari 39 responden ada 19 responden yang mendapatkan pendampingan anggota keluarga dan 20 responden belum mendapatkan pendampingan dari anggota keluarga. 


\section{Analisis Bivariat}

\section{Variabel Perilaku Pencarian Pengobatan}

Tabel 4. Frekuensi Variabel Perilaku Pencarian Pengobatan

\begin{tabular}{lrr}
\hline $\begin{array}{c}\text { Variabel Perilaku } \\
\text { Pencarian } \\
\text { Pengobatan }\end{array}$ & Frekuensi & $\begin{array}{c}\text { Persentase } \\
(\boldsymbol{\%})\end{array}$ \\
\hline Ya & 17 & 48,7 \\
Tidak & 22 & 51,3 \\
\hline Total & $\mathbf{3 9}$ & $\mathbf{1 0 0 , 0}$ \\
\hline
\end{tabular}

Sumber: Data Primer 2020

Berdasarkan tabel 5.3 diatas diketahui bahwa dari 39 responden 17 responden yang melakukan perilaku pencarian pengobatan secara tepat yaitu hanya melakukan terapi ARV dan melakukan pengobatan di fasilitas pelayanan kesehatan yang tepat sedangkan 22 lainnya masih melakukan perilaku pecarian pengobatan yang kurang tepat.
Analisis bivariat dilakukan untuk mengetahui hipotesis penelitian apakah ada hubungan dari pendampingan anggota keluarga dengan perilaku pencarian pengobatan (Health Seeking Behavior) pada orang dengan HIV AIDS atau biasa disebut ODHA di wilayah Kabupaten Madiun. Analisis bivariat adalah analisis yang digunakan untuk menganalisis hubungan (baik bersifat correlational, causal), untuk mengetahui hubungan pemberian pendampingan keluarga dengan perilaku pencarian pengobatan pada ODHA di Kabupaten Madiun dapat dihitung menggunakan uji statistik. menggunakan Chi Square. Berikut ini merupakan hasil yang diperoleh setelah dilakukan analisis hubungan menggunakan aplikasi statistik data :

Tabel 5. Tabel Tabulasi Silang Hubungan Pendampingan Anggota Keluarga dengan Perilaku Pencarian Pengobatan pada ODHA

\begin{tabular}{|c|c|c|c|c|c|}
\hline \multirow{3}{*}{$\begin{array}{c}\text { Pendampingan } \\
\text { Keluarga }\end{array}$} & \multicolumn{4}{|c|}{ Perilaku Pencarian Pengobatan } & \multirow[t]{3}{*}{ p-value } \\
\hline & \multicolumn{2}{|c|}{ Ya } & \multicolumn{2}{|c|}{ Tidak } & \\
\hline & $\mathbf{n}$ & $\%$ & $\mathbf{n}$ & $\%$ & \\
\hline $\mathrm{Ya}$ & 17 & 89.5 & 2 & 10.5 & 0,000 \\
\hline Tidak & 0 & 0 & 20 & 100 & \\
\hline Total & 17 & 43.6 & 22 & 56.4 & \\
\hline
\end{tabular}

Sumber : Data Primer 2020

Berdasarkan tabel tabulasi silang 5 diatas diketahui dari 39 responden sebanyak $89,5 \%$ atau 17 responden melakukan pencarian pengobatan secara tepat dengan mendapatkan pendampingan oleh anggota keluarga . Sedangkan dari 22 Responden yang tidak melakukan perilaku pencarian pengobatan secara tepat terdapat $10,5 \%$ atau 2 responden yang mendapatkan pendampingan anggota keluarga tetapi tidak melakukan perilaku pencarian pengobatan secara tepat dan 20 responden lainnya tidak melakukan perilaku pencarian pengobatan secara tepat karena tidak mendapatkan pendampingan anggota keluarga.
Berdasarkan hasil analisis statistik dengan uji Chi Square diatas diketahui bahwa nilai $p$ value adalah $0,000 \leq 0,05$ menunjukan bahwa terdapat hubungan antara variabel independen yaitu pendampingan oleh anggota keluarga dan variabel dependen yaitu perilaku pencarian pengobatan (Health Seeking Behavior) pada orang dengan HIV AIDS di wilayah Kabupaten Madiun. Sedangkan hasil analisis data yang telah diperoleh dari 39 responden nilai RP atau ratio prevalens adalah 0,105 . Hal ini menunjukan ada hubungan antara kedua variabel dan variabel pendampingan keluarga menjadi faktor protektif atau vaktor pelindung. Hal 
tersebut menunjukkanresponden ODHA yang mendapatkan pendampingan memiliki peluang 0,105 kali lebih kecil melakukan perilaku pecarian pengobatan yang tidak tepat.

\section{PEMBAHASAN}

\section{Karakteristik Orang dengan HIV AIDS di Wilayah Kabupaten Madiun}

Karakteristik orang dengan HIV AIDS di wilayah Kabupaten madiun sebagian besar berusia diatas 30 tahun pernyaataan ini didukung oleh data penderita HIV AIDS KPAD Kabupaten Madiun yang menyatakan sebanyak 343 orang atau 69,2\% dari jumlah keseluruhan ODHA yang ada di wilayah Kabupaten Madiun berusia antara 31 hingga 60 tahun. Berdasarkan hasil data yang deperoleh dari 39 responden menunjukan bahwa orang dengan HIV AIDS di wilayah Kabupaten Madiun masih belum mendapatkan pendampingan keluarga meski keluarga telah mengetahui status responden sebagai penderita HIV AIDS.

Menurut departemen kesehatan tahun 2008 juga disebutkan bahwa salah satu cara penularan HIV AIDS adalah melalui penularan seksual. Penularan HIV AIDS secara seksual dapat melalui kemungkinan bahwa pasangan telah terinfeksi HIV AIDS atau penularan melalui hubungan seksual dengan berganti- ganti pasangan. Sedangkan dalam perilaku pencarian pengobatan sebagian responden juga belum melakukan perilaku pencarian pengobatan secara tepat dengan hanya melakukukan terapi ARV ddi fasilitas pelayanan kesehatan yang sesuai. Hal ini menunjukan bahwa beberapa penderita HIV AIDS di wilayah Kabupaten Madiun belum mendapatkan pendampingan keluarga sehingga berpengaruh pada perilaku pencarian pengobatan yang dilakukan.

\section{Pendampingan Anggota Keluarga dengan Orang dengan HIV AIDS di Wilayah Kabupaten Madiun}

Berdasarkan penelitian yang telah dilakukan pada 39 responden yaitu orang dengan HIV AIDS yang ada di wilayah Kabupaten Madiun dengan cara wawancara dibantu dengan instrument penelitian berupa kuesioner penelitian diketahui bahwa sebagian responden yang seluruhnya telah membuka status pada anggota keluarga belum mendapatakan pendampingan secara penuh dari anggota keluarga. Hal ini didukung oleh hasil penelitian yang menunjukan bahwa ada 20 responden yang belum mendapatkan pendampingan anggota keluarga secara penuh dan 19 responden mendapatkan dukungan penuh dari anggota keluarga mereka.

Berdasarkan hasil wawancara ODHA yang belum mendapatkan pendampingan mereka hanya mengandalkan pendampingan dari KPAD Kabupaten Madiun jika mengalami masalah terkait dengan status dan kondisinya sebagai ODHA mulai dari proses pengobatan hingga pendampingan dalam menghadapi stigma yang mereka alami.

Menurut teori yang dikemukakan oleh Friedman keluarga memiliki beberapa bentuk dukungan (Friedman, 2010) yang termasuk kedalah dukungan keluarga adalah dukungan emosional melalui pemberian motivasi atau dorongan semangat serta dukungan pendampingan pengobatan pada anggota keluarga yang mengalami sakit. Selain itu dukungan yang diberikan oleh anggota keluarga akan menjadi faktor penguat untuk seseorang dalam berperilaku. Maka dari itu berdasarkan hasil penelitian beberapa responden yang tidak mendapatkan pendampingan oleh anggota keluarga 
cenderung tidak melakukan perilaku pencarian pengobatan dengan tepat .

Perilaku Pencarian Pengobatan (Health Seeking Behavior) pada Orang dengan HIV AIDS di Wilayah Kabupaten Madiun

\section{Berdasarkan data yang didapat melalui penelitian yang telah dilaksanakan di wilayah Kabupaten Madiun masih terdapat beberapa orang dengan HIV AIDS atau ODHA yang melakukan pengobatan selain pengobatan ARV yaitu pengobatan tradisional atau alternatif dengan alasan ingin mencoba pengobatan lain setelah mendapatkan informasi bahwa pengobatan tersebut dapat mengobati berbagai macam penyakit, selain itu juga menyatakan kepercayaan mereka tentang pengobatan selain terapi ARV yang mereka pilih dapat mendukung pengobatan yang mereka jalani. Bahkan beberapa pernah berhenti mengkonsumsi ARV dan mengganti dengan pengobatan tradisional ataupun alternatif karena keyakinan mereka bahwa penyakit mereka dapat diobati dan disembuhkan dengan metode pengobatan selain terapi ARV yang mereka pilih.}

Soekidjo Notoatmojo

menyebutkan dalam buku kesehatan masyarakat ilmu dan seni, salah satu bentuk perilaku kesehatan adalah Perilaku seseorang dengan sakit dan penyakit, yaitu bagaimana manusia berespons, baik secara pasif (mengetahui, bersikap, dan mempresepsi penyakit dan rasa sakit yang ada pada dirinya dan luar dirinya), maupun aktif (tindakan) yang telah dilakukan sehubungan dengan penyakit dan sakit tersebut.

Perilaku dengan sakit dan penyakit sendirinya sesuai dengan tingkat-tingkat pencegahan penyakit. Salah satu bentuk respons seseorang dengan penyakit dengan melakukan pencarian pengobatan (health seeking behavior), yaitu perilaku untuk melakukan atau mencari pengobatan, misalnya berusaha mengobati sendiri penyakitnya atau mencari pengobatan ke fasilitas kesehatan modern (puskesmas, mantra, dokter, dan sebagainya) maupun ke fasilitas kesehatan tradisional. Perilaku pencarian pengobatan yang tepat untuk Orang dengan HIV AIDS atau ODHA adalah melakukan terapi ARV secara rutin di fasiltas pelayanan kesehatan yang sesuai.

\section{Hubungan \\ Pemberian \\ Pendampingan Anggota Keluarga dengan Orang dengan HIV AIDS di Wilayah Kabupaten Madiun}

Berdasarkan hasil analisis data menggunakan aplikasi statistik menggunakan uji Chi Square diketahui bahwa terdapat hubungan antara pendampingan anggota keluarga dengan perilaku pencarian pengobatan atau health seeking behavior pada orang dengan HIV AIDS atau ODHA di wilayah Kabupaten Madiun, hal ini ditujukan dengan hsil analisis yang menunjukan nilai $p$ value yaitu $0,000 \leq$ 0,05 .

Selain itu dari hasil analisis data yang telah diperoleh diketahui nilai RP atau ratio prevalens menunjukan nilai 0,105 yang menunjukan ada hubungan antara kedua variabel akan tetapi variabel pendampingan keluarga tidak menjadi faktor resiko untuk variabel perilaku pencarian pengobatan atau ODHA, karena responden ODHA yang mendapatkan pendampingan berpeluang lebih kecil yaitu 0,105 (nilai RP $\leq 1$ ) melakukan perilaku pecarian pengobatan yang tidak tepat atau yang belum sesuai dengan pengobatan yang tepat dilakukan oleh ODHA yaitu hanya terapi ARV dibandingan dengan ODHA yang mendapatkan tidak pendampingan keluarga secara penuh. 
Hasil penelitian ini sejalan dengan penelitian yang dilakukan oleh Meliana depo pada tahun 2010 yang menyatakan bahwa ada hubungan antara dukunmgan keluarga dengan praktik pencarian pengobatan oleh masyarakat di Kota Makasar (Depo, 2014). Penelitian lain yang sejalan dengan penelitian ini adalah penelitian yang dilakukan oleh Vivin Istiya dan Ariana pada tahun 2015 yang menyatakan dukungan dan motivasi dari anggota keluarga menjadi salah satu faktor yang berhubungan dengan perilaku pencarian pengobatan pada penderita kusta di Kabupaten Pati (Ariana, 2016).

Berdasarkan hasil wawancara yang telah dilakukan diketahui bahwa lebih banyak orang dengan HIV AIDS atau ODHA yang melakukan terapi ARV akan tetapi juga melakukan pengobatan dengan metode lain seperti pengobatan tradisional atau alternatif maupun pengobatan sendiri dengan membuat ramuan atau racikan sendiri dirumah tanpa melakukan konsultasi dan arahan dari tenaga kesehatan, dari 39 responden ada 19 responden yang mendapatkan pendampingan anggota keluarga dan 20 responden belum mendapatkan pendampingan dari anggota keluarga. Sedangkan dari 19 responden yang mendapatkan pendampingan keluarga hanya 17 responden yang melakukan perilaku pencarian pengobatan secara tepat. Sedangkan 2 responden lainnya telah mendapatkan pendampingan anggota keluarga akan tetapi belum melakukan perilaku pencarian pengobatan secara tepat dangan alasan ketika mereka melakukan terapi ARV mereka merasakan efek samping seperti mual, pusing, hingga masalah kulit sehingga mereka menghentikan konsumsi ARV.

Teori Perilaku yang dikemukakan oleh Lawrence Green menyebutkan bahwa salah satu faktor yang mempengaruhi perilaku adalah adanya faktor penguat atau reinforcing factors. Faktor ini meliputi faktor sikap dan perilaku tokoh masyarakat, tokoh agama, sikap dan perilaku para petugas termasuk petugas kesehatan dan sikap dan perilaku dukungan keluarga. Untuk berperilaku sehat, masyarakat kadangkadang bukan hanya perlu pengetahuan dan sikap positif dan dukungan fasilitas saja, melainkan diperlukan perilaku contoh (acuan) dari para tokoh masyarakat, dari anggota keluarga, hingga petugas kesehatan. Berdasarkan teori tersebut jika pendampingan dari anggota keluarga sebagai faktor penguat tidak didapatkan, maka akan berpengaruh pada perilaku pencarian pengobatan yang dilakukan oleh orang dengan HIV AID atau ODHA.

Hasil dari penelitian ini menujukan bahwa masih banyak responden ODHA yang belum mendapatkan pendampingan dari anggota keluarga secara penuh meskipun keluarga telah mengetahui status responden sebagai penderita HIV AIDS. Hal ini menyebabkan ODHA yang tidak mendapatkan pendampingan dari anggota keluarga secara penuh cenderung melakukan perilaku pencarian pengobatan yang kurang tepat karena merasa kurangnya motivasi dan arahan dari anggota keluarga sebagai orang terdekat mereka bahkan beberapa ODHA sempat mendapatkan stigma dari anggota keluarganya.

\section{KESIMPULAN}

Berdasarkan hasil penelitian dan pembahasan tentang hubungan hubungan pendampingan anggota keluarga dengan perilaku pencarian pengobatan(Health Seeking Behavior) pada orang dengan HIV AIDS atau ODHA diwilayah Kabupaten Madiun maka hasil penelitian ini dapat disimpulkan bahwa : Karakteristik Orang dengan HIV AIDS di Wilayah Kabupaten sebagian besar berusia 
diatas 30 tahun, dan cara penularan terbanyak ditularkan melalui heteroseksual atau hubungan suami istri. Berdasarkan hasil penelitian yang menunjukan bahwa masih terdapat responden yang belum mendapatkan pendampingan dari anggota keluarga meski anggota keluarga telah mengetahui statusnya sebagai ODHA. Berdasarkan hasil penelitian diketahui bahwa masih terdapat responden (orang dengan HIV AIDS atau ODHA) yang tidak melakukan perilaku pencarian pengobatan atau health seeking behavior secara tepat. Berdasarkan hasil analisis data menggunakan aplikasi statistik menggunakan uji Chi Square diketahui bahwa terdapat hubungan antara pendampingan anggota keluarga dengan perilaku pencarian pengobatan atau health seeking behavior pada orang dengan HIV AIDS atau ODHA di wilayah Kabupaten Madiun.

\section{DAFTAR PUSTAKA}

Anggarini, A. (2014) Faktor-Faktor Yang Mempengaruhi Perilaku Pemeriksaan VCT Pada Ibu Hamil di Wilayah Kerja Puskesmas II Melaya Kabupaten Jembrana Provinsi Bali. Undergraduate Thesis. Bali: Program Studi Diploma IV Kebidanan STIKES Ngudi Waluyo.

Ariana, V. I. (2016) Dengan Pencarian Pengobatan Pada Penderita Kusta Multy Bacillary ( Mb ) Di Kabupaten Pati Tahun 2015. Undergraduate Thesis Semarang: Fakultas Ilmu Keolahragaan Universitas Negeri Semarang

Departemen Kesehatan Jawa Timur (2017) Profil Kesehatan Jawa Timur 2017. Surabaya: inas Kesehatan Jawa Titmur.
Departemen Kesehatan RI (2008) Profil Kesehatan Indonesia 2008. Jakarta: Departemen Kesehatan RI

Departemen Kesehatan RI (2018) Profil Kesehatan Indonesia 2018. Jakarta: Departemen Kesehatan RI

Ervina, L. and Ayubi, D. (2018) 'Peran Kepercayaan Terhadap Penggunaan Pengobatan Tradisional Pada Penderita Hipertensi Di Kota Bengkulu Bengkulu City'. Indonesian Journal of Health Promotion and Behavior, 1(1), pp. 1-9.

Friedman, M. (2010) Buku Ajar Keperawatan keluarga: Riset, Teori, dan Praktek. Jakarta: EGC.

Hapsari, T. dan Azinar, M. (2017) 'Praktik Terapi Antiretroviral pada Anak Penderita HIV/AIDS'. HIGEIA (Journal of Public Health Research and Development), 1(2), pp. 39-48.

Komisi Penanggulangan AIDS Daerah Kabupaten Madiun (2019) Pendampingan Orang dengan HIV AIDS Kabupaten Madiun per Juli 2019. Kabupaten Madiun: Komisi Penanggulangan AIDS

Komisi Penanggulangan AIDS Jawa Timur (2019) Prevalensi Kasus HIV AIDS Jawa Timur 2019. Surabaya: Komisi Penanggulangan AIDS.

$\begin{array}{ccr}\text { Luthfiana (2012) } & \text { Hubungan } \\ \text { Pengetahuan } & \text { dan } & \text { Sikap } \\ \text { Terhadap } & \text { Perilaku } & \text { Berisiko } \\ \text { HIV/AIDS } & \text { Pada } & \text { Pekerja }\end{array}$


Bangunan Di Proyek World Class University. Undergraduate Thesis. Jakarta: Fakultas Kesehatan Masyarakat Universitas Indonesia.

Murni, S., Green, C.W., Djauzi, S., Setyanto, A., Okta, S. (2009) Hidup dengan HIV/AIDS. Jakarta: Yayasan Spiritia.

Notoatmodjo, S. (2010) Ilmu Perilaku Kesehatan. Jakarta: Rineka Cipta.

Notoatmodjo, S. (2011) Kesehatan Masyarakat Ilmu dan Seni. Jakarta: Rineka Cipta.

Notoatmodjo, S. (2012) Promosi kesehatan dan Perilaku Kesehatan. Jakarta: Rineka Cipta.

Nursalam. (2013) Metodologi Penelitian Ilmu keperawatan. Jakarta: Salemba Medika.

Rumengan, D. S. S. and Kandou, J. M. L. U. G. D. (2015) 'FaktorFaktor yang Berhubungan dengan Pemanfaatan Pelayanan Kesehatan Pada Peserta BPJS Kesehatan di Puskesmas Paniki Bawah Kecamatan Mapanget Kota Manado. E-Journal Universitas Sam Ratulangi, 5(2), pp. 88-100.

Saryono. (2011) Metode Penelitian Kualitatif Dan Kuantitatif. Yogyakrta: Nuha Medika.

Sugiyono. (2007) Metode Penelitian Pendidikan Pendekatan Kuantitatif, Kualitatif. Bandung: ALFABETA.

Sugiyono. (2013) Metode Penelitian Kualitatif Dan Kuantitatif Dan
$R$ Dan D. Bandung. Bandung: ALFABETA.

UNAIDS (2018) Report on the global AIDS epidemic. switcerland.

Winardi. (2004) Manajemen Perilaku Organisasi. Cetakan ke. Jakarta: Kencana Prenada Media Group. 